\title{
Investigate the Determinant Factors of Employee Motivation: The Case of Harare Brewery Share Company in Harare, Ethiopia
}

\author{
BINIYAM KEBEDE DESTA \\ Lecturer of Management, College of Business (Department Head of MBA) \\ Addis Ababa Medical and Business College in Dire Dawa, Ethiopia \\ EYOBE FEKADU ASFAWE (MBA) \\ Harare Brewery Area Sales Manager \\ Leadstar University College Dire Dawa, Ethiopia
}

\begin{abstract}
The study intends to examine the determinant factors of employee motivation: The case of Harare Brewery Share Company in Harare, Ethiopia. The objectives of the study were: Do demographic profiles of employee's leads to differences in employees' motivation; to examine the determinants of employees' motivation; to investigate the major challenge that hinders Harare Brewery Share Company in motivating their employees and to generate possible strategies to mitigate the challenges and to enhance employees' motivation. Explanatory research design was adopted using quantitative and qualitative methods. The study targeted 205 respondents but 181 returned the survey questions, indicating a response rate of 88 per cent. Stratified sampling technique was used to select marketing, purchasing, finance, HR and production department's employees. Data analysis involved standard deviation and variance to determine the proportions and frequency of the variables. Order logit (O logit) regression models as well as Chi-square test was employed to establish the relationship and strength between the dependent and independent variables before settling on the most appropriate of these methods. The results showed that age, education level, salary and benefit, working condition, recognition, promotion, training and development, supervisory relationship and relationship with co-worker significantly determine employee's motivation, whereas sex and experience dose not significantly determine the employee's motivation in Harare Brewery Share Company.
\end{abstract}

Keywords: Employee's motivation, Harare Brewery Share Company

DOI: $10.7176 /$ RHSS/9-19-01

Publication date:October $31^{\text {st }} 2019$

\section{INTRODUCTION}

\subsection{Background of the Study}

The world is going in an enormous change. All organizations, regardless of size, market, and technology, want to be successful and maintain a constant progress even in a current highly competitive business environment. In order to achieve those goals and objectives, strategies must be developed and well-implemented with the effective utilization of all capable resources. A few companies believe that their employees are an important asset that can lead them to overcome difficulties, exceed their limits and reach prosperity. In contrast, companies that put their personnel in the center of the business, maintaining a positive and strong relationship with its employees, persuading them towards task fulfillment are proved to result in higher affectivity and productivity (Anka, 1988). Nowadays the biggest task of the human resource manager is to motivate and retain employees. Managing human resource is the most difficult task that a manager has to do. Human beings are by nature not a homogeneous entity. They have several of needs, aspirations, as well as differing perceptions of what establish appropriate rewards for effective motivation. Thus motivating workers requires an in-depth understanding of the human nature, individual differences and perceptions of appropriate rewards and incentives, with a combination of extrinsic and intrinsic rewards. Good pay or salaries is also a valuable instrument to play a significant role to improving employee performance and also improve the productivity of an organization. A well-managed organization can motivate and retain employees. Puts human resources into action, improves level of efficiency of employees, and builds friendly relationship, leads to achievement of organizational goals and leads to stability of work force. On top of this, well-motivated employees are more productive and creative towards achieving organizational goals, than less motivated employees. According to Armstrong (2009), high performance is achieved by well-motivated people who are prepared to exercise discretionary effort. Employee motivation is the procedure in which the organization should motivate their employee in the form of bonus, rewards, and some other incentives etc. only for the reason to attain the organizational objectives. The individual is a complex creature. So every employee in an organization is inspired by some various kind of tactic. To motivate employees it is necessary to appreciate how motivation works; that is, understanding motivation theories and how they can be put into practice. Essentially, the way employees are motivated should be undertaken in a more systematic and coordinated manner, even this should be supported with frequent and 
realistic surveys of the need and attitude of the employees. However, today, companies are also facing challenges in employee retention. Acknowledging the important role of employees and the huge influence they bring towards organizational effectiveness, companies are trying to retain employees by creating motivation and a healthier workplace. This is very important because if the personnel are not focused well, it associates with a decline in business productivity and effectiveness. Unless and until the employees are motivated and satisfied, an organization cannot foster to success (Manzoor 2011). This is due to the fact that motivation of employees in an organization is influenced by a number of factors; and hence, the purpose of this study is to evaluate the determinants of employee's motivation in Harare Brewery Share Company.

\subsection{Statement of the Problem}

Generally most businesses, organizations and their managers are faced with numerous challenges. One of such challenges is in the area of management which refers to the utilization of resources effectively and efficiently in order to achieve an organizations goals and objectives. Some of these managerial challenges are obvious in matters concerning employees such as reimbursement, recruitment, performance management, training and career development, health and safety, benefits, motivation and administration amongst others. The human resource is the most vital of all resources among other factors of production and the human capital is what distinguishes one organization from the other (Maimuna \& Rashad, 2013). Therefore, for organizations to survive and remain relevant and competitive, it is essential for them to be able to entice and maintain efficient and effective employees in a bid to enhance productivity (Sunia, 2014).

Employees make up the workforce of any organization as such they are an integral part of the organization. Aluko (2014) stated that an organization is only as good as the workforce that runs the organization. This is to say that when employees are motivated chances are that their morale would be high as such performance and productivity levels would increase thereby to a large extent boosting overall organizational performance level. In order to achieve high levels of productivity as such boost organizational performance or productivity, managers therefore need to continually seek ways of ensuring that their employees stay motivated. This is because a lack of employee motivation leads to reduced productivity which is harmful to organizational performance and continuous success.

According to Eskil Heinesen (2014), the motivation of employees is a significant aspect of job satisfaction, attendance, and performance, which impact organizational effectiveness. An understanding of what aspects of the organization, its values, and its mission are appealing to employees provides the organization with insight into how best to design the work of the organization to be meaningful and rewarding. The review in the literature on public and privet sector employee motivation has revealed the importance of motivating employees for better performance, and how it contributes to productivity and effectiveness. In this regard, early research conducted by Azrain (2015) concludes that salary and benefits, working environment, relationship with co-worker, Training and Development and Recognition are extrinsic and intrinsic determinants of motivation.

Previous studies on employee motivation mainly focus on the effects of motivation on employee's performance or organization performance. Not many studies have been studied on its determinant factors. Even though research on factors affecting employee motivation have been done in different organizations, this research is necessary for the fact that employees in different environments and who are affiliated to different cultures cannot attain motivation from the same factors. As far as the knowledge of the researcher is concerned and the researcher wish to bridge the gaps identified from literatures by putting more emphasis the level of employee's motivation and what factors affect it did not get much attention in Harare Brewery Share Company. Consequently, it is necessary to generate relevant evidence through a detail study to highlight strategies for improving the motivation of employees. Among the factors that were considered by researchers are Salary and benefits, Promotion Opportunity, Supervisory relationship, Relationship with co-worker, Working environment, Training and development, Recognition, and Socio - demographic factors (Gender (Sex), Age, Education, and Work Experience) has significant relationship with motivation of employees. Hence, this research proposes to fill all these gaps by investigating the determinant factors affecting employee motivation in Harare Brewery Share Company. Specifically, it finds out the level of employee's motivation, assesses the significant factors of employee motivation, and draws possible strategies to enhance employee's motivation and indicating directions for further research.

\subsection{Research Questions}

The above statements guide the researcher to build up research questions regarding the determinant of employee's motivation in Harare Brewery Share Company; the study were design to seek answers to the following basic questions:

1. Do demographic profiles of employee's leads to differences in employees' motivation?

2. What are the determinants of employees' motivation in Harare Brewery Share Company?

3. What are the major challenges that hinder organizations to motivate in Harare Brewery Share Company? 
4. What possible strategies should be forwarded to enhance employees' motivation in Harare Brewery Share Company?

\subsection{Objectives of the Study}

1.4.1. General objective

The general objective of this study was to examine the determinants of employee's motivation in Harare Brewery Share Company.

1.4.2 Specific objectives

The objectives of this study were to:

1. Do demographic profiles of employee's leads to differences in employees' motivation

2.-- To examine the determinants of employees' motivation in Harare Brewery Share Company.

3.-- To investigate the major challenges that hinders Harare Brewery Share Company in motivating their employees.

4. To generate possible strategies to mitigate the challenges and to enhance employees' motivation in the study area.

\subsection{Research Hypothesis}

The study was to test the hypotheses that:

$\mathbf{H}_{0}$ : There is no significant relationship between determinant factors and employee motivation.

$\mathbf{H}_{1}$ : There is a significant relationship between determinant factors and employee motivation.

\subsection{Significance of the Study}

The finding of this research will provide the following important inputs: more reliable in-depth understanding of the determinant factors of employee motivation and thereby the concerned bodies will be aware of the needs for effective management of motivation; to ensure a stable work environment and well-motivated employees; will help the organizations formulate appropriate employee motivation policies and strategies to enhance employee motivation and assist the company administration and particularly the Human Resource Development Personnel to design and implement strategies on how employees can be motivated and also serve as a source of reference document for future researchers.

\section{THEORETICAL LITERATURE REVIEW}

\subsection{Definitions of Motivation}

Technically the word motivation can be traced back to the Latin word "mover" which means "to move". Motivation is subroutine which begins with a physiological or psychological defect or wants or need that start a manner of acting that is planned to accomplish a goal or objective. Robbins (1994) has emphasized that employee motivation is "The process that accounts for an individual's intensity, direction, and persistence of effort toward attaining a goal". Luthans (2005), on the other hand, fells that it is "Desires wants wishes aims goals needs drives motives and incentives".

Motivation is an internal drives to satisfy an unsatisfied need and the will to accomplish. It is a procedure that initiates through a physiological or psychological want that stimulates a performance that is intended at an objective. It is the concluding product of interface among personality behavior and organizational distinctiveness. It symbolizes those psychological procedures that foundations the stimulation, route, and determination of deliberate actions that are target oriented (Manzoor, 2011). Herzberg defined job satisfaction as recognition, responsibility, and opportunity for advancement as employee motivation factors. Separating satisfiers and dissatisfies he identified dissatisfies as hygiene factors that influences health, comfort and social wellbeing. Removal of these factors will result in dissatisfaction of employees. Hygiene factors include company policy, interpersonal relations, working conditions, salary or job security. Motivation is an employee's intrinsic enthusiasm and drives the employee to accomplish the activities related to work (Chaudhary\& Sharma, 2012).

\subsection{Factors Affecting Employee Motivation}

According to Kamalian et al. (2010), the effects of work, as well as its contributing factors are also of importance for the need satisfaction. As a result, work is seen as a means to pursue other motives.

\subsubsection{Salaries and benefits}

No one works for free, nor should they. Employees want to earn reasonable salary/payment and employees desire their employers to feel that is what they are getting. Money is the fundamental inducement; no other incentive or motivational technique comes even close to it with respect to its influential value. It has the supremacy to magnetize, retain and motivate individuals towards higher performance. Frederick Taylor and his scientific management associate described money as the most fundamental factor in motivating the industrial workers to attain greater productivity (Abadi, et al, 2011). Monetary rewards have seen to be the most important 
motivator for employees; no other reward contributes as effectively as money does (Rynes, Gerhart, \& Minette, 2004). All businesses use pay, promotion, bonuses or other types of rewards to motivate and encourage high level performances of employees. To use salaries as a motivator effectively, managers must consider salary structures which should include the importance organization attach to each job, payment according to performance, personal or special allowances, fringe benefits, pensions etc (Rukhmani et al 2010).

\subsubsection{Work Environment}

Employee level of motivation is also influenced by the quality of the working environment both its physical attributes and the degree to which it provides meaningful work. While a comfortable physical environment is correlated with employee motivation, the relationship is not merely as strong as the relationship between motivation and managerial behavior (Yazdani et al 2011). Work environment plays an essential role since it influences employee motivation. Employees are concerned with a comfortable physical work environment that will ultimately provide extra optimistic level of motivation. Lack of favorable working conditions, amongst other things, can affect badly on the employee's mental and physical well-being. According to Arnolds et al (2001) factors such as working hours, temperature, ventilation, noise, hygiene, lighting, and resources is all part of working conditions. Negative performance will be provoked by poor working conditions since employees job demand mentally and physically tranquility (Irons and Buskist, 2008). Moreover, they warned that if working conditions are two extreme ends i.e. either too favorable or too extreme, this could be taken for granted or ignored by most employees. Furthermore, when employees feel that management does not appreciate or acknowledge their efforts or work done they may use poor working conditions as an excuse to get back at management (Whittaker, 2008).

\subsubsection{Supervisory Relationship}

A good managerial relation is an important factor in fostering employee motivation. Those who act to maintain good relations with their employees exhibit the following behaviors: help with job related problems, awareness of employee difficulties, good communication, and regular feed-back about the performance so that employees always know where they stand. Employees want to have input into decisions that affect them, to feel important and appreciated. They want to be informed and involved at work place. When a job brings recognition and respect, employees are motivated with it. This is an easy condition to create with feedback (Tella, 2007). The evidence that "good management" plays a part in affecting employee motivation puts a responsibility on both the managers and the supervisors in the organization. Management needs information on employee motivation in order to make sound decisions, both in preventing and solving employee problems.

\subsubsection{Promotion Opportunities}

Promotional opportunities affect employee motivation considerably. The desire for promotion is generally strong among employees as it involves change in job content, pay, responsibility, independence and status among others. An average employee in a typical government organization can hope to get two or three promotions in his entire service, though chances of promotions are better in private sector. It is no surprise that the employees take promotion as the ultimate achievement in their career and when it is realized, he/she feels extremely satisfied (Turkyilmaz et al, 2011). If an organization provides employees the necessary factors for promotion such as facilities, ability and skills, then employees will be automatically motivated and satisfied. Promotion and satisfaction have a direct relationship.

\subsubsection{Relationship with Co-workers}

A co-worker is a person who holds a position or rank similar to that of an employee in the same company/organization. Co-workers are a distinct part of the working environment, and employees are expected to work harmoniously with other employees (Iqbal, 2010). People seek friendly, warm and cooperative relationships with others, not only for what these relationships produce in the immediate present, but also for what they provide in those times of need, such as social support. Bagraim, et al, (2007) suggest that employees should be technically, emotionally and socially supportive of one another. Harmonious interactions between an individual and their fellow employees, as well as relations between other fellow employees with each other, have a positive influence on an individual's level of organizational commitment and motivation (Iqbal 2010). Pleasant associations with co-workers have been found to have a positive influence on an individual's level of motivation (Ladebo et al, 2008).

\subsubsection{Recognition}

It is a useful positive tool where usually people get recognized by their work and job done and based on that they receive recognition. Pinar, (2011) stated that employees work harder when they are recognized and appreciated for their effort toward the work and tasks have been given and this is a simple, easy and powerful strengthen system. When employees get recognized and appreciated, they do their best to prove the skill, talents and abilities they have. Furthermore, recognizing employees is also considered a way of communication that strengths and rewards the outcomes people create for your business. For that, leaders should develop recognition system which is powerful for both employees and organization (Hsiu-Fen, 2007). Employees who feel appreciated and recognized are more positive about themselves and their abilities to contribute. It also guarantees 
positive, productive and innovative organization environment. Saying thank you as recognition will make the business successful (David, Louis \& Micheal, 2004).

\subsubsection{Training and Development}

Training provides chances to employees' growth and enhances their knowledge and skills for effective development (Kabir, 2011). Trained workers are more motivated with their job as compared to untrained employees (Abdullah and Djebavni, 2011). These training programs positively raise employeese advancement that is good for competencies (Hunjra, Chani, Aslam, Azam \& Rehman, 2010). By getting these training programs employees are able to get self-assured, evolution of career, and have positive thought for their organizations/companies (Kabir, 2011). The aim of these training and management programs is to amend employees' skills and organization potentialities (Hunjra et al., 2010).

\subsection{Empirical Literature on Employee Motivation}

The result of Farooq and Aslam (2011) study depicts the positive correlation between training development and employee motivation as $\mathrm{r}=.233 \mathrm{sig}=.000$. Thus, we can predict from this finding that it is not possible for the organizations to gain higher returns without best utilization of its human resource, and it can only happen when organizations are able to meet its employee's job related needs in timely fashion. Training is the only ways of identifying the deprived need of employees and then building their required competence level so that they may perform well to achieve organizational goals. Moreover, the result of the study of Sultana (2012) conducted in service sector of Pakistan telecom, states the $\mathrm{R}^{2}$ as 0.501 which means that $50.1 \%$ of variation in employee performance is brought by training programs. Further, the T-value was 8.58 that explain training is good predictor of employee performance. Also, in a similar research, (Akerele, 2001) equated the comparative position of ten motivational tools such as pay, training, security, etc. considered external to the job, and other internal factors like employee well-being, good relationships with managers, responsibility etc. among 80 employees of an organization. It was assumed that greater value will be put on internal rather than external job factors. However, findings failed to validate the assumption as it was revealed that two extrinsic factors sufficient compensation and job safety were rated as the most important tools. The above are practical works undertaken by various scholars in the area of motivation and productivity. Based on these empirical examinations and conclusions, one may possibly deduce that both intrinsic and extrinsic motivational factors are very essential in improving workers' productivity levels in the workplace. As such an individual's performance levels can be expected to result in higher productivity if the right motivational tools are put in place. Manzoor (2012) presented the problem that what affects the employee motivation and to study the relationship between employee motivation organizational effectiveness. This research is done in Bhawalpur. The findings of the research are factors like empowerment and recognition have an effect on employee motivation. An organization that uses empowerment and recognition tends to increase the work motivation. Also, there is an optimistic relationship between employee motivation and organizational effectiveness. Organizations should treat their employees well and appreciate them in order to get growth. Asim (2013) presented the impact of motivation level amongst the workers' performance with the mediating of the training needed in Pakistan universities. The problem targeted at the research is the relationship between rewards, promotion on the employee motivation with special effects from the worker's performance more specifically on education sector. The research was carried out from 118 respondents. In this research correlation and regression methods were used to consider the data. The findings of the study explain that the universities of Pakistan should improve the salary and reward system in order to get the desired performance from the university employees. Zameer et. al, (2014) presented the problem that examine the impact of employee motivation on employees performance. 150 questionnaire were distributed to the beverage companies (Pepsi.Coke .Gourmet) in Pakistan. The methodology used is regression and correlation to analysis the variables. The findings brought by this research is if the beverage companies uses tools like enrichment, job security, incentives, reasonable salaries the employee gets motivated directly and performance also increases. It is recommended that the top management should focus on motivating employees to get positive result in performance. Kahn (2010) has examined the influence of on payment, recognition, promotion on employee work motivation. The statistical analysis result shows that there is strong relationship between reward and employee motivation. This study has greatly contributed in revealing the fact that different tactics and policies would have different motivational impact on diverse people. A study by Ashgar Ali and Mohammed (2012) pointed out that there is positive impact of financial rewards on employee's motivation and satisfaction. That is, financial rewards lead to employee's motivation. It is also discovered that new entrants in to an industry are highly motivated and the working conditions, environment and superior's behavior plays a vital role in determination of their satisfaction level. Therefore, from above all empirical research discussion we can observe that employees' motivation can be affected by numerous factors. This helps us to conclude that a positive change in one of the above factors may offer positive significant effect on employees' motivation. 


\section{RESEARCH METHODOLOGY}

\subsection{Research Design}

This study employed an explanatory research design. Since the purpose of explanatory research design is to explain and interpret the relationships between two or more aspects of a situation or phenomenon, in this research it enabled researchers to explain and interpret the relationship between employee's motivation and its determinants. The study also employed a survey design administered through structured questionnaire. To determine employee motivation in Harare Brewery Share Company; and to describe as well as to explore and interpret the relationship between employee's motivation and its determinants the study was used summery statistics and Order logit (O logit) regression.

\subsection{Target Population}

All the items under consideration in any field of inquiry constitute a population. (Sekeran, 2001) defines a population as "the entire group of people, events, or thing of interest that the researcher wishes to investigate". The total number of employees is 478 , which is the total population working in 5 departments in Harare Brewery Share Company, (HR Development Harare Brewery Share Company Data 2019). The actual populations are marketing, purchasing, finance, production and HRM departments.

\subsection{Sampling Technique}

This study possessed the probability sampling techniques since the sampling units under the study have equal chance being a sample. There are four types of probability sampling technique, and among of those this study was used the stratified probability sampling techniques.

\subsection{Sample Size determination}

To determine the sample size and representative of the target population, the study was used statistical instrument formula. The following formula used for the calculation of the sample size since it is relevant to studies where a probability sampling method is used (Watson, 2001). The sample size of study computed as follows.

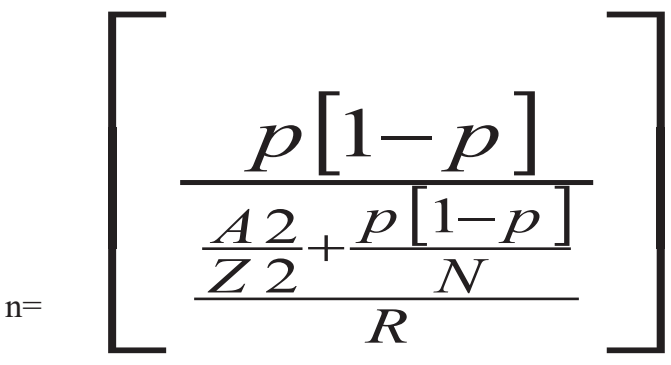

Where, $\mathrm{n}=$ sample size required $=205$

$\mathrm{N}=$ number of population $=478$

$\mathrm{P}=$ estimated variance in the population $=50 \%$

$\mathrm{A}=$ margin of error $=5 \%$

$\mathrm{Z}=$ confidence level $=1.96$ for $95 \%$ confidence

$\mathrm{R}=$ estimated response rate $=96 \%$

The proportional stratified sampling for each stratum was determined by $n / N=205 / 478=0.43$ which means that $43 \%$ of each clusters as calculated in the table.

Table 3.1 proportional stratified sample

\begin{tabular}{|c|c|c|}
\hline Department & Total & Sample $43 \%$ \\
\hline Marketing & 73 & 31 \\
\hline Purchasing & 40 & 17 \\
\hline HR & 38 & 16 \\
\hline Finance & 30 & 13 \\
\hline Production & 297 & 128 \\
\hline TOTAL & 478 & 205 \\
\hline
\end{tabular}

Source: HR Development Harare Brewery Share Company Data (2019)

\subsection{Methods of Data Analysis}

According to Sarantokos (1998), the analysis of data allows the researcher to organize data collected during the study in order to assess and evaluate the findings and to arrive at some valid, reasonable and relevant conclusion. 
In this study, before processing the responses, data preparation was carried out on the completed questionnaires through editing, coding, transcribing (entering), and cleaning the data. Descriptive analysis using measures of central tendency was used such as; mean median and mode, as well as measures of variability such as the standard deviation and variance to determine the proportions and frequency of the variables. Spearman's Correlation and $\mathrm{O}$ logit regression models as well as $\boldsymbol{X}^{2}$ was employed to establish the relationship and strength between the dependent and independent variables before settling on the most appropriate of these methods. Data analysis was done using tools namely; Statistical Package for Social Scientist (SPSS version 23) and STATA software version 14. The qualitative data obtained from key informants were analyzed through multiple response methods.

\subsection{Model Specification}

\subsubsection{Chi-square Test of Association}

Chi-square test of association is used to test whether there is significant relationship/association between two categorical variables or not.

Model: $\quad \boldsymbol{X}^{2}=\frac{\sum \sum\left(\mathrm{0}_{\mathrm{ij}}-\mathrm{E}_{\mathrm{ij}}\right)^{2}}{\mathrm{E}_{\mathrm{ij}}{ }^{2}}$

Where: $\mathrm{O}=$ observed count $\mathrm{E}=$ expected count

\subsubsection{Ordinal Logistic Model}

The ordered logit model is a regression model for an ordinal response variable. The model is based on the cumulative probabilities of the response variable: in particular, the logit of each cumulative probability is assumed to be a linear function of the covariates with regression coefficients constant across response categories. In this research, the relation between Employee Motivation and the explanatory variables- Salary and benefits (SB), Promotion Opportunity (PO), Supervisory relationship (SR), Working Environment (WE), Relationship with Co-worker (RC), Training and Development (TD), Recognition (R), and Demographic factors(DF) (such as Gender, Age, Education and Experience ) and dependent variable-Employee Motivation (EM) variables will be assumed to be logistic over the course of the study.

Generally, we can express the ordinal logistic model for k predictors with P-1 levels response variable as:

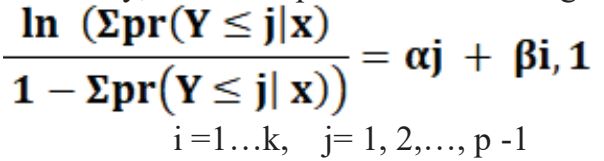

Where: $\alpha \mathrm{j}$ or $\beta \mathrm{o}=$ Threshold

$$
\beta \mathrm{i}=\text { Parameter } \mathrm{X} i 1=\text { Sets of factors or predictors }
$$

A logistic regression model is developed to test the research hypotheses in order to determine the significance of the determinants of employee motivation. The dependent variable and independent variables will be developed by taking the averages of all questions related to them.

\section{Results and Discussion}

\subsection{Response rate}

The survey was conducted between June and July 2019. Questioners were distributed to 205 randomly chosen employees. All the employees' survey respondents were located in Harare Brewery Share Company

Table 4.1: Response rate

\begin{tabular}{lll}
\hline Participants & Frequency & Percentage \\
\hline Responded & $\mathbf{1 8 1}$ & $\mathbf{8 8}$ \\
Non responded & $\mathbf{2 4}$ & $\mathbf{1 2}$ \\
Total & $\mathbf{2 0 5}$ & $\mathbf{1 0 0}$ \\
\hline
\end{tabular}

Source: Survey2019

According to Table 4.1above, out of the 205 questionnaires administered, 181 were returned fully completed, giving a response rate of $88 \%$. Out of 4 respondents targeted for interviews, all of them were actually interviewed, implying a response rate of $100 \%$. Out of this sample, 19 and 5 from Core processor and Supportive processor respectively total 24 questionnaires were not returned giving a response rate of $12 \%$. The overall response rate of the respondents was thus $88 \%$. With that high response rate of $80 \%$, the findings of the study were representative of the actual population and could therefore, be generalized, as observed by (Sekaran, 2003). Overall, 181 responses were received, giving a response rate of 88 percent. This shows that the response rate considered as fair. Dillman, (2007) suggests that the response rate for a personal delivery approach varies considerably from the lower of 28 percent to the highest of 50 percent. 


\subsection{Reliability}

Cronbach's alpha reliability analysis was conducted on the independent variables in order to determine the reliability of the instrument used. Nunnally (1978) has suggested 0.70 as the acceptable level for reliability measure. Alpha values ranged from 0.724 to 0.925 , thus indicating an acceptable level of reliability.

Table 4.2: Cronbach Alpha Coefficients of Explanatory Variables

\begin{tabular}{lcc}
\hline Scale & No. of items & Cronbach alpha Coefficient \\
\hline Salary and Benefit & 6 & 0.779 \\
Working Condition & 5 & 0.724 \\
Recognition & 5 & 0.725 \\
Supervisory Relationship & 8 & 0.925 \\
Promotion & 5 & 0.726 \\
Training and Development & 6 & 0.823 \\
Relationship with Co-worker & 6 & 0.840 \\
\hline
\end{tabular}

Source: Survey, 2019

\subsection{Factor Analysis}

According to Coakes and Steed (2007), Factor Analysis is a data reduction technique used to reduce a large number of variables to a smaller set of underlying factors that summarize the essential information contained in the variables. Factor Analysis is more frequently used as an exploratory technique when to achieve the objective of summarizing the structure of a set of variables. Factor analysis was to run by using principle component analysis according to items in each domain across and components extracted by way of varimax rotation. KaiserMeyer- Olkin (KMO) is measure of sampling adequacy also examined to validate factor analysis, between the ranges of 0 to 1 , with 0.6 as the minimum level. The results of the Barlett's test were significant for all variables and $\mathrm{KMO}$ is the above-recommended value of 0.6 for all variables meaning that it indicates sampling adequacy.

Table 4.3: Kaiser-Meyer- Olkin (KMO)

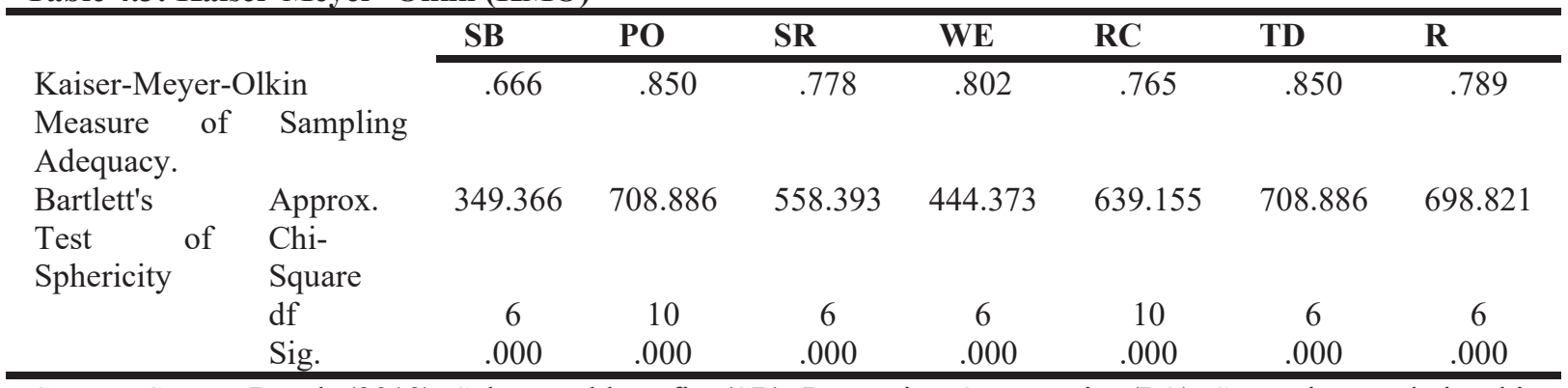

Source: Survey Result (2019), Salary and benefits (SB), Promotion Opportunity (PO), Supervisory relationship (SR), Working Environment (WE), Relationship with Co-worker (RC), Training and Development (TD), Recognition (R)

\subsection{Descriptive Analysis}

\subsubsection{Demographic Characteristics of Employee Respondents}

The demographic characteristics include: sex, age, educational status, job position, overall experience, and monthly income. The descriptive statistics results of demographic characteristics of the sample employees have been depicted as follows. As indicated in table 4.2., from the total 181 respondents, 50.7\% (91) were male respondents who took slightly small share of the total respondents and the remaining $49.3 \%$ (90) were female respondents. This presupposes that generally, the margin between males and females is minimal. This implied that there was fairly (equal) representation of the male and female employees in Harare Brewery Share Company. The SPSS results showed that, the largest proportion of the respondents fall on the age group between a range of $36-45$ years, which is $40.9 \%$ (77), followed by the second largest proportion of the respondents aged between 26 - 35 years, which is $27.1 \%$ (49). The third largest proportion of the age group is between $46-55$ years, which is $22.7 \%$ (41), followed by an age group less than 25years, which is also $8.3 \%$ (15) and above 56 years is $1.1 \%$ (2). We can conclude that the majority of the respondents are aged between $36-45$ years. The data collected showed that, the largest proportion of the respondents, which is $58 \%$ (105), possessed Undergraduate Degree and the second largest proportion of the respondents, which is 19.9\% (36) TVET graduate and the third largest proportion of the respondents, which is $13.3 \%$ (24) holds Postgraduate Degree and above. The remaining respondents, which is $7.7 \%$ (14), have College Diploma and 1.1\% (2) High School Complete. The fact that the majority of the respondents were well-educated means that they well understood the question from the questionnaire and the responses obtained were reliable. The collected data shows that, the highest percentage of the respondents, which is $43.1 \%$ (78) served the organization for greater than 17 years. The second largest 
percentage of the respondents, which is $33.1 \%$ (60), worked for 11-16 years and the third largest percent of the respondents, i.e. $14.9 \%(27)$ served the organization for $6-10$ years. The rest were $8.8 \%$ (16) with service years of less than 5 years.

\subsection{Motivation Level/Status of Employees}

From the descriptive analysis of the study, respondents reported low level of motivation with their respective mean scores for Recognition (2.1), Working Condition (2.2), Training and Development (2.3) and Promotion (2.5) determinants. The determining factor with the smallest mean score of motivation was Salary and Benefit. Study participants were reported moderate level of motivation for Supervisory Relationship (3.1), Relationship with Co-worker (2.9) and Salary and Benefit (2.8). In general, the mean motivation status for all employees in the sample was 2.5(Table 4.4). Therefore, the average motivation level of employees for the sample was considered to be medium.

Table 4.4: Mean Scores of Motivation status of Employees

\begin{tabular}{lccc}
\hline & \multicolumn{3}{c}{ Descriptive Statistics } \\
\cline { 2 - 4 } Variables & N & Mean & Std. Deviation \\
\hline Salary and Benefit & 181 & 2.8 & 1.13 \\
Working Condition & 181 & 2.2 & 0.93 \\
Recognition & 181 & 2.1 & 0.94 \\
Supervisory Relationship & 181 & 3.1 & 1.11 \\
Promotion & 181 & 2.5 & 0.99 \\
Training and Development & 181 & 2.3 & 0.99 \\
Relationship with Co-worker & 181 & 2.9 & 0.99 \\
Employee Motivation & 181 & 2.5 & 0.99 \\
\hline
\end{tabular}

Source: Survey, 2019

4.6. Result of Employees Motivation Composite Analysis

The mean scores of perceptions and expectations of respondents toward the determinants of motivation were shown in table 4.5.

Table 4.5: Mean Scores of Employees Perceptions and Expectations

\begin{tabular}{lccccc}
\hline Determinants of Motivation & $\begin{array}{c}\text { Perception } \\
\text { Scores }\end{array}$ & $\begin{array}{c}\text { Standard } \\
\text { deviation }\end{array}$ & $\begin{array}{c}\text { Expectation } \\
\text { Scores }\end{array}$ & $\begin{array}{c}\text { Standard } \\
\text { deviation }\end{array}$ & $\begin{array}{c}\text { Gap Score } \\
\text { (Perception - } \\
\text { Expectation) }\end{array}$ \\
\hline Salary and Benefit & 1.82 & .82 & 3.34 & 1.64 & -1.52 \\
Working Condition & 2.16 & .93 & 3.28 & 1.62 & -1.12 \\
Recognition & 2.06 & .94 & 3.52 & 1.52 & -1.46 \\
Supervisory Relationship & 3.15 & 1.11 & 3.52 & 1.40 & -0.37 \\
Promotion & 2.47 & .98 & 3.44 & 1.47 & -0.97 \\
Training and Development & 2.32 & .99 & 3.47 & 1.45 & -1.15 \\
Relationship with Co-worker & 2.96 & 1.01 & 3.59 & 1.38 & -0.63 \\
Average score for all Determinants & 2.40 & .67 & 3.50 & 1.14 & -1.10 \\
\hline
\end{tabular}

Source: Survey, 2019

4.6.1 Gap Analysis of Employees Motivation (Perceptions - Expectations)

Expectations and perceptions were both measured using the 5-point Likert Scale whereby the higher numbers indicate higher level of expectation or perception. In general, employees' expectation exceeded the perceived level of motivation shown by the perception scores. This resulted in a negative gap score (Perception Expectation). From the table one can understand that the average score of employees' expectations was mean value of 3.50 and the overall perception score was 2.40 . The score shows a -1.10 difference. This means that the expectations are higher than the perceived employee's motivation. In general, the negative score for the employee's motivation dimension were showed that there is a room for improving employee's motivation in Harare Brewery Share Company. As can be seen, the highest gap score were Salary and Benefit $(-1.52)$, followed by Recognition (- 1.46), Training and Development (- 1.15), Working Condition (- 1.12), Promotion (- 0.97), Relationship with Co-worker (- 0.63) and Supervisory Relationship (- 0.37) of which the gap score in all dimension is pronounced and need attention from the company administration and particularly the Human Resource Development Personnel.

\subsection{Inferential Analysis}

Inferential statistics is the procedure by which we reach a conclusion about a population based on the 
information obtained from the sample drawn. Therefore among inferential statistics, we employed chi-square test and ordinal logistic regression. The chi-square test statistics was used to analyze the association between variables. Chi-square is simply an extension of a cross-tabulation that gives us more information about the relationship. However, it provides no information about the direction of the relationship (positive or negative) between the two variables. It deals the associations/relationships among two variables and test hypotheses about relationships between two or more ordinal level variables. The following table presents the Chi-Square test results depicting the association of employee's motivation with individual demographic variables.

Table 4.6: The Chi-Square Test Statistics Showing Association between Variables

\begin{tabular}{lllll}
\hline Variables & Sex & Age & Experience & Education \\
\hline Pearson Chi-Square & 12.013 & 21.651 & 21.704 & 15.232 \\
df & 4 & 16 & 12 & 16 \\
Sig. & 0.017 & 0.155 & 0.041 & 0.508 \\
\hline
\end{tabular}

Source: Survey, 2019

Table 4.6: depicted that employee's motivation had a significant association with sex (p-value $<0.05$ ). However, age, overall experience and education had no significant association with employee's motivation ( $p$ value $>0.05$ ).

Table 4.7: Motivation Differences between Male and Female Employees

\begin{tabular}{lrr}
\hline & \multicolumn{2}{c}{ Sex of Respondents } \\
\cline { 2 - 3 } Employee's Motivation & Male (\%) & Female (\%) \\
\hline Very low & $22(24.8)$ & $20(21.5)$ \\
Low & $37(40.2)$ & $29(30.0)$ \\
Moderate & $25(27.4)$ & $32(37.7)$ \\
High & $5(5.7)$ & $7(8.1)$ \\
Very high & $2(1.8)$ & $2(1.8)$ \\
\hline Total & $\mathbf{9 1 ( 1 0 0 . 0 )}$ & $\mathbf{9 0 ( 1 0 0 . 0 )}$ \\
\hline
\end{tabular}

Pearson chi2 (4) $=\mathbf{1 1 . 0 0 2 2} \operatorname{Pr}=\mathbf{0 . 0 2 7}$

Table 4.7 depicted the motivation differences between male and female employees across the categories of motivation in Harare Brewery Share Company. The results revealed that motivation of male employees for very low and low category (65\%) are significantly greater than that of female $(51.5 \%)$ for the same category. Similarly, the percentage of moderately motivated females $(37.7 \%)$ is significantly higher than that of male employees $(27.4 \%)$ in Company. The results also reported that motivation of female employees for very high and high categories $(9.9 \%)$ is slightly greater than that of males $(7.5 \%)$ for the same categories in Harare Brewery Share Company. This shows that female employees are highly motivated than that of males in Harare Brewery Share Company.

4.8 Determinants associated with Employees Motivation

Table 4.8: The Marginal Effects of the Ordered Logit Model for Determinants of Employee's Motivation

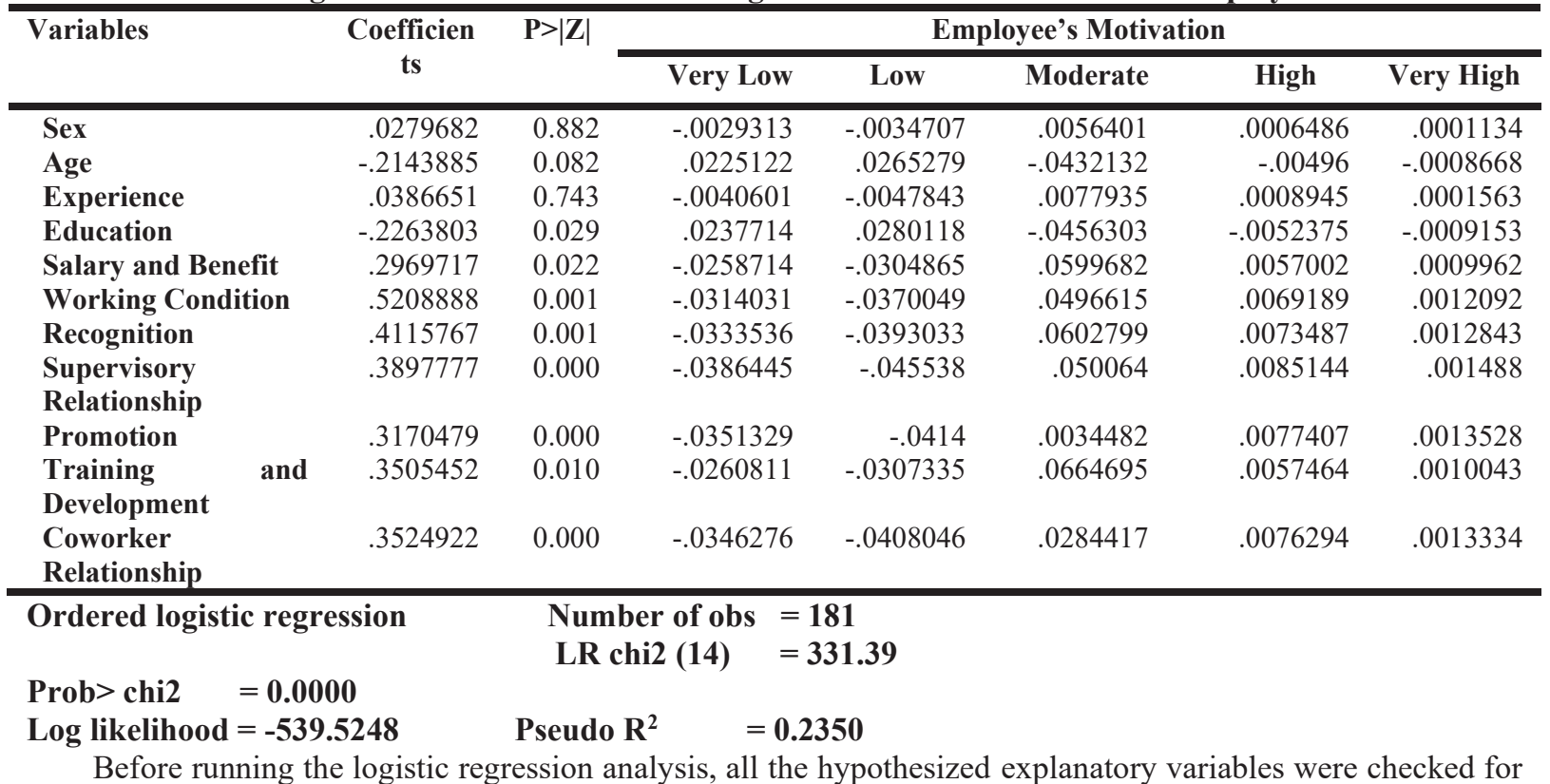


the fitness and adequacy of the model, and consequently found to be significantly adequate and fitted well. Therefore $\mathrm{H}_{1}$ is accepted. The ordered logistic regression model was also fitted to estimate the effects of a unit change in the individual hypothesized explanatory variable towards the variance of motivation of employees in Harare Brewery Share Company.

The results showed that age, education level, salary and benefit, working condition, recognition, promotion, training and development, supervisory relationship and relationship with co-worker significantly determine employee's motivation in Harare Brewery Share Company. Whereas sex and experience, dose not significantly determine the employee's motivation in the study area.

Thus, the results of the marginal changes of each significant explanatory variable on Employee's Motivation level categories were analyzed as follows.

The study results reported that age negatively influenced the motivation of employees at $10 \%$ probability. Its marginal effect exhibited that a one unit (year) increase in the age of employees, given that all of the other variables in the model are held constant, would result in a probability of decrease in moderate, high, and very high motivation level categories by about $4.3 \%, 0.4 \%$, and $0.09 \%$ respectively, whereas that of low and very low would increase by $2.7 \%$ and $2.3 \%$ respectively.

Another factor influencing motivation of employees was the level of education, which has a negative effect on motivation of employees at 5\% significance level. The estimated coefficient of the variable suggested that, being other variables in the model kept constant, a one unit increase in the educational level of employees would result in the probability of decrease in moderate, high, and very high motivation level categories by about $4.6 \%$, $0.5 \%$ and $0.09 \%$ respectively where as that of low and very low would increase by $2.8 \%$ and $2.4 \%$ respectively.

In Harare Brewery Share Company employee's motivation was found to be influenced positively by the availability of adequate salary and benefits at 5\% level of significance. The marginal effect showed that, an increase of one unit of adequate salary and benefits of employees, other variables being constant, would increase the probability of their motivation level for moderate, high, and very high categories by $6 \%, 0.6 \%$ and $0.1 \%$ respectively, while their motivation of low and very low categories would decrease by $3.1 \%$ and $2.6 \%$ respectively.

Availability of favorable working condition was deemed to be an important element to improve motivation of employees. Working condition in the study area was found to have positive and significant effect on motivation level of employees at $1 \%$ level. The marginal effect on the availability of favorable working condition implies, given that other variables in the model are held constant, that a unit increase in favorable working environment would increase the probability of motivation for moderate, high, and very high categories by about $5 \%, 0.7 \%$ and $0.01 \%$ respectively, whereas that of low and very low category decreases by $3.7 \%$ and $3.1 \%$ respectively.

Recognition encompasses several ways to recognize employees motivation such as greeting for better jobs, attach thanks to their paycheck, acknowledge employee milestones, staff gathering outside the organization, appreciation for coming up with new ideas, holding celebrations for success, arranging frequent contests and other team building activities, etc. The model results revealed that recognition was assessed to have a positive and significant influence on employee's motivation at 1\% level. Holding all other variables in the model constant, as recognition of employees in Harare Brewery Share Company increases, the probability of their motivation of moderate, high, and very high categories increase by about $6 \%, 0.74 \%$ and $0.13 \%$ respectively, whereas that of low and very low category decreases by $3.9 \%$ and $3.3 \%$ respectively.

Promotion is another factor determining employee's motivation in Harare Brewery Share Company, which belongs to providing more responsibility or authority to workers to motivate them in their work places. The results reported that there was a positive effect of promotion on the motivation of employees at $1 \%$ level of confidence. As the effect of a one unit of recognition increases, the probability of employee's motivation for moderate, high, and very high categories increase by about $0.3 \%, 0.8 \%$ and $0.14 \%$ respectively, whereas that of low and very low category decreases by $4.1 \%$ and $3.5 \%$ respectively, other things being constant.

Employee's motivation was found to be influenced positively and significantly by coworker's relationship, which is friendly, warm and cooperative relationships among workers, at $1 \%$ level of significance. Given that all other variables in the model kept constant, the marginal effect showed that, as employee's relationship with coworkers in Harare Brewery Share Company in the study area increases, the probability of motivation for moderate, high, and very high categories increase by about $2.8 \%, 0.8 \%$ and $0.1 \%$ respectively, whereas that of low and very low category decreases by $4.1 \%$ and $3.5 \%$ respectively.

Regarding Training and Development in Harare Brewery Share Company, the model results exposed that equity was estimated to have a positive influence on employee's motivation at $1 \%$ level of confidence. The effect of a unit increase in Training and Development, other variables held constant, the probability of the employee's motivation for moderate, high, and very high categories increase by about $6.7 \%, 0.6 \%$ and $0.1 \%$ respectively, whereas the probability of low and very low category decreases by $3.1 \%$ and $2.6 \%$ respectively.

The last determining factor affecting motivation of employees was supervisory relationship. The result also 
showed that supervisory relationship has positive and significant effect on Harare Brewery Share Company motivation at $1 \%$ level. The marginal effect indicated that, given that other variables in the model held constant, an increase of a unit of supervisory relationship in Harare Brewery Share Company the probability of employee's motivation of moderate, high, and very high categories increase by about $5 \%, 0.9 \%$ and $0.1 \%$ respectively, whereas the probability of low and very low category decreases by $4.5 \%$ and $3.8 \%$ respectively.

\subsection{Major Challenges that deter the motivation of employees}

As it is indicated in the results of the study presented so far, the level of employee's motivation in Harare Brewery Share Company was low and not as expected. This is because of the fact that there have been some challenges to combat so that in Harare Brewery Share Company can improve the motivation of their employees. The main ones are presented as follows: Absence of transparency, accountability \& unfair working conditions; unsatisfactory working inputs and environment; lack of adequate man power and experience sharing; absence of recognition, incentives for outstanding employees; unfair benefits, absence of salary scale and reasonable salaries in response to the cost of living; inadequate leadership skills to evaluate the performance of employees; absence of strategic focused \& planned- driven leadership; lack of empowering, listening and trusting of employees; lack of training packages \& educational incentives; absence of coaching and monitoring activities; lack of dwellings for employees and inequitable treatment of workers.

\section{CONCLUSIONS AND RECOMMENDATIONS}

\subsection{Conclusion}

The aim of this research is to investigate the determinants of employee's motivation in Harare Brewery Share Company. Nine determining factors of motivation namely, Salary and Benefit, Recognition, Working Condition, Training and Development and Promotion, Supervisory Relationship and Relationship with Co-worker are used as an instrument for the study. Based on the above results, it can be concluded that majority of the company workers have low level of motivation for Salary and Benefit, Recognition, Working Condition, Training and Development and Promotion, whereas moderate level of motivation for Supervisory Relationship and Relationship with Co-worker. Totally, the aggregate level of employee's motivation in Harare Brewery Share Company is found to be low. Additionally, there is significant variation in the level of motivation across sex of employees. Accordingly, female employees are motivated more than that of males in Harare Brewery Share Company.

\subsection{Recommendation}

Based on the findings of the study the following recommendations and strategies are worth drawn. The results of the study revealed that co-worker relationship, promotion, training and development, salary and benefit, recognition and working condition are significantly influencing motivation of employees in Harare Brewery Share Company in that order. The administration as well as Harare Brewery Share Company heads and office holders should give due attention for the aforementioned determinants and devise mechanisms to improve the motivation of employees in the administration. Company heads and office holders should recognize the efforts of employees and appreciate their valuable performance towards organization. This gives employees more fulfillment getting recognition from the manager. Company should give due attention for employee motivation by reviewing financial and non-financial benefit packages to increase motivation among employees of company. Employees need up-to-date knowledge and skills to perform well because training continually nourish their work attitude and behavior. Organizations should invest more on training and development program, which enable employees to accomplish their task effectively and efficiently. It is advisable for the managers to give freedom to employees in doing their task by provision of necessary resources to achieve the desired result. People want to be respected and valued for their contributions. Employee respond to recognition expressed through appreciation of their good work because it confirms their work is valued. The manager of the organization should assign work fairly in an organization and talk with employees freely and friendly and organization should develop good relationship among employees. Provision of opportunities for further training and development both short term and long term is imperative for enlarged motivation and improving the knowledge and skill of employees.

Further studies should also be conducted on why female employees are highly motivated than that of males, and why employees with lesser work experience are highly motivated than that of employees with greater work experience in Harare Brewery Share Company and other Public and privet Organization.

\section{REFERENCES}

- $\quad$ Abadi, F. E., Jalilvand, M. R., Sharif, M., Salimi, G. A., \&Khanzadeh, S. A. (2011). A Study of Influential Factors on Employeese Motivation for Participating in the In-Service Training Courses Based on Modified Expectancy Theory. International Business and Management, 2 (1), 157-169.

- Abdulla, J \&Djebavni, R (2011). 'Determinants of Job Satisfaction in the UAE A Case Study of Dubai 
police', vol 40, no. 1, pp. 126-146.

- Akerele, A. (2001). Role of labour in productivity. Nigeria Journal of Industrial Relation, 5, 50-58.

- Akhtar, M. F., Ali, K., Sadaqat, S \&Hafeez, S. (2011). Extent of training in Banks and its Impact on Employee's Motivation, and, involvement in job. Interdisciplinary Journal of Contemporary, Research in Business. 2(12): 793-806.

- Ali, Reena and Ahmed, MShakil (2009). The Impact of Reward and Programs on Employees Motivation and satisfaction. International Review of Business Research Papers, vol. 5, no. 4 page 250-279.

- Aluko, N. (November, 2014). 6 Challenges Facing Manufacturing Companies in Nigeria and

- Alyah Mohammad Saad and norsiahBinti Mat, (2014). Evaluating effectiveness of training and Development the Kirkpatrick model, Asian journal of Business, Vol.2 No11 (14-24).

- Amjad et al. (2016), The Impact of Motivation on the Employee Performance and Job Satisfaction in IT Park (Software House) Sector of Peshawar, Pakistan International Journal of Academic Research in Business and Social Sciences, Vol. 6, No. 9 ISSN: 2222-6990

- Anka, L. M. A.(1988), March-April. Corporate Objectives and Self Development: The Specialist International. Journal of Institute of Management Specialist, 3, 5.

- Armstrong, M. (2009). A Handbook of Human Resources Management Practice, 10th Edition, London: Kogan Page.

- Arnolds, C.A., \&Boshoff, C. (2001). The challenge of motivating top management: A need satisfaction perspective [Electronic version]. Journal of Industrial Psychology, vol. 27(1): 39-42.

- Asghar Ali, Muhammad Naseem Akram (2012), Impact of Financial Rewards on Employee's Motivation and Satisfaction in Pharmaceutical Industry, Pakistan. Global Journal of Management and Business Research Volume 12 Issue 17 Version 1.0.

- Asim, M. (2013). Impact of Motivation on Employee Performance with Effect of Training: Specific to Education Sector of Pakistan. International Journal of Scientific and Research Publications, 3(9), 1-9

- Azar, M \& Shafighi, A. (2013). The Effect of Work Motivation on Employees' Job Performance: International Journal of Academic Research in Business and Social Sciences, Vol. 3, No. 9 ISSN: 22226990.

- $\quad$ Bargraim, J., Cunningham, P., Potgieter, T. \&Viedge, C. (2007). Organizational behaviour: A contemporary South African perspective. Pretoria: Van Schaik.

- Bhumika Gupta and Jeayaram Subramanian (2014) Factors Affecting Motivation among Employees in Consultancy Companies International Journal of Engineering Science Invention ISSN (Online): 2319 6734, ISSN (Print): 2319 - 6726 www.ijesi.org

- Chandrasekar. K. (2011). Workplace Environment and its Impact on Organizational Performance in Public Sector Organizations, International Journal Of Enterprise Computing and Business Systems, Vol:1, Issue:1

- Chaudhary, N \& Sharma, B. (2012). Impact of Employee Motivation on Performance (Productivity) In Private Organization: International Journal of Business Trends and Technology, volume2, Issue 4.

- Chiang, C.F., \& Jang, S.C. (2008). An expectancy theory model for hotel employee motivation. International Journal of Hospitality Management, 27: 313-322.

- Costen, W., \& Salazar, J. (2011). The impact of training and development on employee job satisfaction, loyalty, and intent to stay in the lodging industry. Journal of Human Resources in Hospitality \& Tourism, 10(3), 273-284.

- Danish, R. Q., \& Usman, A., (2010). Impact of Reward and Recognition on job Satisfaction and Motivation: An Empirical Study from Pakistan. International Journal of Business and Management, 5 (2), 159-167.

- David, S., Louis, A. M., Micheal, I. M., (2004). "Why your employees are losing motivation”, Working Knowledge for business leaders, 4(10), pp. 1-4

- DemetLeblebici (2012). Impact of workplace quality on employee's productivity: Case study of a bank in turkey, Journal of Business, Economics \& Finance, Vol.1 (1)

- Döckel, A., Basson, J. \& Coetzee, M. (2006). The effect of retention factors on organizational commitment: an investigation of high technology employees. SA Journal of Human Resource Management, 4(2):20-28.

- Farooq, M. \& Khan, M. A. 2011.Impact of Training and Feedback on Employee Performance. Far East Journal of Psychology and Business. 5(1): 23-33.

- Farooq-E-Azam Cheema, (2013). Impact of Non-monetary Rewards on Employees' Motivation , Journal of Management and Social Sciences, Karachi-Pakistan Vol. 9, No.2, (Fall 2013) 23-30

- Ghana. Kpakpakpa.com. Retrieved 13th January, 2017 from http://kpakpakpa.com/spotlight/chal lengesfacing-manufacturing-in-nigeria-ghana/

- Hossain, M, Kamal \& Hossain, Anowar(2012). Factors Affecting Employee‘s Motivation in Fast Food Industry: The Case of KFC UK LTD\|. Research Journals of Economics, Business and ITC, Vol.5, pp.22-29, 
viewed 2 November 2012, <http://ojs.journals.cz/index.php/RJEBI/article/view/223/227.

- Hsiu-Fen, L., (2007). "Effects of Extrinsic and intrinsic motivation on employee knowledge sharing intentions", Journal of Information Science, 33(2), pp. 135-149

- Hunjra, AI, Chani, MI, Aslam, S, Azam, M \&Rehman, KU (2010), 'Factors effecting job satisfaction of employees in Pakistani banking sector', African Journal of Business Management, vol. 4, no. 10, pp. 21572163.

- Iqbal, A. (2010) An empirical assessment of demographic factors, organizational ranks and organizational commitment. International Journal of Business andManagement, 5(3):16-27.

- Iqbal, N. A. (2014). Impact of training and Development on Employee performance. Arabian Journal of Business and Management Review, Vol.2, No.4.

- Irons, J., \&Buskist, W. (2008). Operant Conditioning. In S. Davis, \& W. Buskist (Ed.), 21st Century psychology: a reference handbook. (pp. 1-329-1-340). Thousand Oaks, CA: SAGE Publications, Inc.

- J K Sharma and RaazMaheshwari (2013). Human Resource Development and its Technique. Inter. J. Educat. Res.Technol., Vol 4 [2] : 85- 87

- Jibowo, A. A. (2007). - Effect of motivators and hygiene factors on job performance among extension workers in the former Western State of Nigeriall. The Quarterly Journal of Administration, 12 (1):45-54.

- Kabir, .M. (2011), Factors affecting employee job satisfaction of pharmaceutical sector, Australian Journal of Business and Management Research, Vol. 1 No. 9, pp: 113-123.

- Kahn K, Farooks,Ullah M.,(2010), The Relationship between Rewards and Employee Motivation in Commercial Bank of Pakistan; Research journal of international Studies-issue 14, pp. 36-54

- Kamalian, A. R., Yaghoubi, N. M., \&Moloudi, J., (2010). Survey of Relationship between Organizational Justice and Empowerment (A Case Study). European Journal of Economics, Finance and Administrative Sciences, 24, 165-171.

- Khan and Iqbal,2013 “An Investigation Of The Relationship Between Work Motivation (Intrinsic \& Extrinsic) And Employee Engagement"

- Khan, K. U (2010). The Relationship between Rewards and Employee Motivation in Commercial Banks of Pakistan. Research Journal of International Studies, 14, 37-52.

- Ladebo, O.J., Awotunde, J.M. \&AbdulSalaam-Saghir, P. (2008). Coworkers ${ }^{\text {ee }}$ and supervisor interactional justice: correlates of extension personnel's job satisfaction, distress, and aggressive behaviour. Institute of Behavioral \&Applied Management, 9(2):206-225

- Luthans, et al. 2005. The psychological capital of Chinese workers: Exploring the relationship with performance. Management and Organization Review, 1: 247-269

- MahmoodAsad and JomaMahfod, (2015). Training and Development and its Impact on the Employee's Performance A Study of Agility Company-Kingdom of Bahrain, International Review of Management and Business Research Vol. 4 Issue.3 ISSN: 2306-9007.

- Maimuna, M. N., \& Rashad, Y. F. (2013). The impact of employee training and development on employee productivity. Global Journal of Commerce and Management Perspective, 2(6), 91-93

- Manzoor Q. A. (2011). Impact of employeesee motivation on organizational effectiveness. European Journal of Business and Management www.iiste.org ISSN 2222-1905 (Paper) ISSN 2222-2839 (Online) 3 (3).

- Manzoor, Q. A. 2012. Impact of Employees Motivation on Organizational Effectiveness. European Journal of Business and Management, 3. 3(1), 1-12.

- Mehmood. N, Irum. S \&Ahmed. S, (2012). A study of factors affecting job satisfaction (Evidence from Pakistan).Interdisciplinary journal of contemporary research in business. Vol 4, No 6.

- Mondy, R. W. 2012. Human Resource Management. Twelfth Edition. Pearson Education Limited, England.

- Muchai, M. M. and Mwangi, B. (2012). Effect of Employee Rewards and Recognition on Job Performance in Kenya's Public Sector: A Case Study of Nakuru Water and Sanitation Ltd. International Journal of Science and Research, 3 (9), pp. 2151-2156.

- Oluseyi, S., \& Ayo, H. T., (2009). Influence of Work Motivation, Leadership Effectiveness and time Management on Employees' Performance in some Selected Industries in Ibadan, Oyo State, Nigeria. European journal of Economics, Finance and Administrative Sciences, 16, 7-17.

- Pinar, G., (2011). “The Relationship between Reward Management System and Employee Performance with the Mediating Role of Motivation: A Quantitative Study on Global Banks", Procedia Social and Behavioral Sciences, 24(2011), pp. 1510-1520

- Rashid Saeed, ShireenMussawar, Rab Nawaz Lodhi, Anam Iqbal, HafizaHafsaNayab and SomiaYaseen, (2013). Factors Affecting the Performance of Employees at Work Place in the Banking Sector of Pakistan: Middle-East Journal of Scientific Research 17 (9):, ISSN 19909233.

- Reena, A. \& Ahmed, M. S. (2009). The impact of reward and recognition programs on employee's 
motivation and satisfaction: an empirical study. International review of business research papers 5 (4) June 2009 pp. 270-279.

- $\quad$ Robbins, S.P. (1994). Essentials of Organizational Behaviour (4th.Ed). Publisher: Prentice Hall,

- Rukhmani, K., Ramesh, M., \&Jayakrishnan, J., (2010). Effect of Leadership Styles on Organizational Effectiveness. European Journal of Social Sciences, 15 (3), 365-369.

- Rynes, S. L., Gerhart, B., \&Minette, K. A., (2004). The Importance of Pay in employee Motivation: Discrepancies between What People say and what they do. Human Resource Management, 43 (4), 381-394.

- Salman K., Irshad M. Z. (2010). Job satisfaction among bank employees in Punjab, Pakistan: A comparative study. European Journals of Social Sciences, 17, 570-577

- Sarantakos, S. (1988), Social Research, Second Edition, Palgrave, New York.

- Sekar,C.(2011). Workplace Environment and its impact on organizational performance in public sector organizations , International Journal of Enterprise Computing and Business SystemInternational Systems, Vol. 1 Issue 1 January 2011.

- Sunia, F. (2014). Factors that predict employee retention in profit and not-for-profit Organizations. Global Journal of Human Resource Management 2(4), 1-8.

- Tella, A., Ayeni, C. O., \&Popoola, S. O., (2007). Work Motivation, Job Satisfaction and Organizational commitment of Library Personel in Academic and Research Libraries in Oyo State, Nigeria. Library Philosophy and Practice, 1-16.

- Turkyilmaz, A. Z., Akman, G., Ozkan, C., \&Pastuszak, Z., (2011). Empirical study of Public sector Employee Loyalty and Satisfaction. Industrial Management and Data Systems, 111 (5), 675-696.

- Watson, Jeff. 2001. How to Determine a Sample Size: Tip sheet \#60, University Park, PA: Penn State Cooperative Extension.

- Whittaker, C. (2008). Hotel operator motives in UK sale and leaseback/management-back transactions. International Journal of Hospitality Management, 27 (4): 641-648.

- Yaseen. A (2013) Effect of compensation factors on employee satisfaction: International Journal of Human Resource Studies. ISSN 2162-3058 2013, Vol. 3, No.1

- Yazdani, B. O., Yaghoubi, N. M., \&Giri, E. S., (2011). Factors affecting the Empowerment of Employees. European Journal of Social Sciences, 20 (2), 267-274.

- Zameer, H., Ali, S., Nisar, W., \& Amir, M. (2014). The Impact of the Motivation on the Employee's Performance in Beverage Industry of Pakistan. International Journal of Academic Research in Accounting, Finance and Management Sciences, 4(1), 293-298.
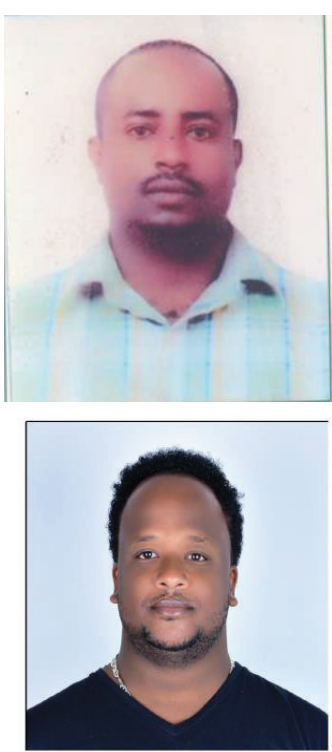

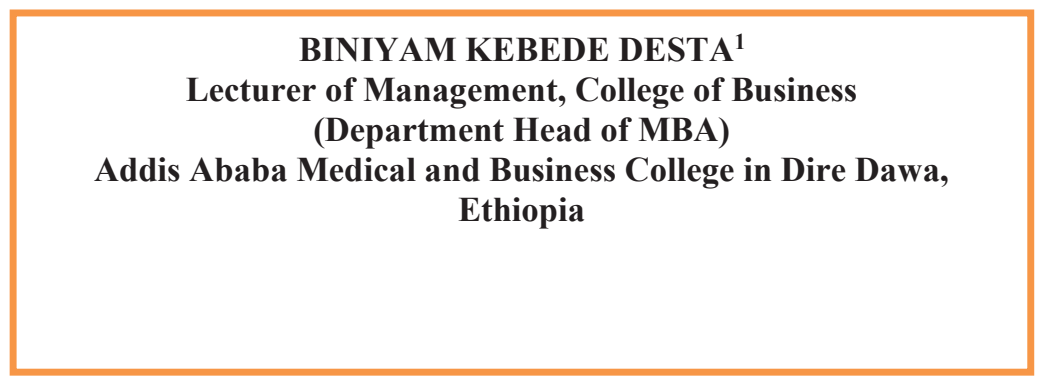

EYOBE FEKADU ASFAWE (MBA) ${ }^{2}$

Harare Brewery Area Sales Manager

Leadstar University College Dire Dawa, Ethiopia 